QUARTA PARTE

\title{
Direito Administrativo
}




\title{
Atos Administrativos Sujeitos a Registro pelos Tribunais de Conta e a Decadência da Prerrogativa Anulatória da Administração Pública
}

\author{
Rafael da Cás Maffini
}

\author{
Advogado em Porto Alegre; \\ Mestre e Doutorando em Direito pela UIFRGS, \\ Professor de Direito Administrativo.
}

\section{INTRODUÇĀO}

O Direito e a Constituição são o Que as Cortes Constitucionais dizem Que são. Tal máxima - referida por Hart ${ }^{\prime}$ - revela-se absolutamente apropriada num sistema judiciário como o brasileiro, em Que o Supremo Tribunal Federal é Qualificado solenemente na Carta Política como o "guardião precípuo da Constituição"z . Demais disso, Questões de política judiciária, notadamente aquelas pertinentes ao excessivo volume de demandas Que deságuam no Poder Judiciário ${ }^{3}$, germinam uma tendência cada vez mais acentuada de concentração decisória de matérias constitucionais no Supremo Tribunal Federal, em óbvio detrimento dos mecanismos de controle difuso de constitucionalidade ${ }^{4}$. Por certo, a interpretação constitucional oriunda do Pretório Excelso merece respeito e impóe obediência, dada a legitimação institucional Que lhe é imanente.

i "A supreme tribunal has the last word in sayng what the law is and, when it has said it, the statement that the count was wrong has no conscQuences within the system: no one's rights or duties are thereby altercd. .... This leads to another from of the denial that courts in deciding are cver bound by rules: "The law (or the constitution) is what the court say it is." (HART, Herbert L.A., The concept of Law, London: Oxford, 1961, p. 138).

2 "CF, Art. 102. Compete ao Supremo Tribunal Federal, precipuamente, a guarda da Constituição, ...".

3 O próprio Poder Público, não se pođe olvidar, é um dos principais responsáveis pelo incomensurável número de demandas que vertem ao Poder Judictário.

4 A Emenda Constitucional $n^{\circ} 45$, de 08.12.2004 (publicada no DOU de 31.12.2004) cristalizou ainda mais tał tendência, ao ampliar ou atribuir vinculatividade às decisões oriundas do STE, especialmente com a redação dada aos Artigos $102, \S 2^{\circ}$ ("As decisöes definitivas de mérito, proferidas pelo Supremo Tribunal Federal, nas açöes diretas de inconstitucionalidade e nas açöes declaratórias de constitucionalidadc produziräo effcácia contra todos e efeito vinculante, relativamente aos demais órgãos do Poder Judiciário e à administraçăo pública direta e indireta, nas esferas federal, estadual c municipal") e I03-A ("O Supremo Tribunal Federal poderá, de oficio ou por provocação, mediante decisão de dois terços dos seus membros, após reiteradas decisóes sobre matéria constitucional, aprovar súmula que, a partir de sua publicação na imprensa oficial, terá efeito vinculante em relação aos demais órgãos do Poder /udiciário e à administração pública direta e indircta. nas esferas federal, cstadual e municipal, bem como proceder à sua revisăo ou cancelamento, na forma estabelecida em lef"). Antes da EC 45/04, a referida tendência jáa aparecia na legislação infraconstitucional. especialmente na Lei $n^{\circ} 9.868 / 99$ (Art. 28, $\S$ único) e na Lei $n^{\circ} 9.882 / 99$ (Art. 10, $\S 3^{\circ}$ ). 
No entanto, o mister institucional cometido ao Supremo Tribunal Federal de ser a boca Que pronuncia as palavias da Constituição Federal ${ }^{5}$, seu intérprete autêntico ${ }^{6}$, pois, não o imuniza de críticas. Ao jurista se impõe uma avaliação atenta das decisões exaradas pelo STF - ou por Qualeuer outro órgão jurisdicional - seja para revelar e reconhecer a correção dos fundamentos Que ensejaram a decisão, seja para apontar eventuais equívocos de premissa ou, em sentido mais amplo, a incorreção inerente ao julgamento analisado.

$\mathrm{Ta}$ posicionamento crítico, longe de significar afronta ao importante papel desempenhado pelo STF, o coloca em relevo. O produto da atividade jurisdicional necessariamente carece de mediatização humana e, como tal, apresenta-se suscetível a erros. Tanto quanto falível, a condição humana traz consigo a característica da mutabilidade, razão pela Qual se permite cogitar de uma alteração de posicionamento ${ }^{7}$, mesmo oue levado a efeito pelo Supremo Tribunal Federal.

Ou seja, o papel da Ciência Jurídica, e pois, daqueles que dela se ocupam, deve visar sempre à construção, mesmo Que, para tanto, tenha de destruir, no plano teórico, os argumentos jurídicos empregados como fundamentos para as decisões judiciais.

O presente ensaio almeja justamente promover uma análise crítica de uma orientação intrínseca a decisões recentemente levadas a efeito pelo Supremo Tribunal Federal. Tratamse dos Mandados de Segurança $n^{\circ} 24.958^{8}, 24.997^{9}, 25.015^{10}, 25.036^{14}, 25.037^{12}$, $25.090^{13}, 25.095^{14} \mathrm{e} 25.192^{15}$, todos impetrados contra atos praticados pelo Tribunal de Contas da União.

5 Tal consideração não é mais do que uma paráfrase a Montesquieu (MONTESQUfEU, O espirito das leis, trad. Pedro Vieira Mota. 4. ed. São Paulo: Saraiva, 1996. p. 176), Que obviamente não pode ser interpretada com uma ode endereçada a um comportamento autômato e restritivo dos integrantes daquela Corte.

- Aqui, intérprete autêntico é expressão utilizada no sentido empregado por Kelsen. Verbis. "a interpretação feita pelo órgão aplicador do Direito é sempre autêntica. Ela cria Direito. ... Mas autếntica, isto é, criadora de Direito, é-o a interpretação através de um órgáo aplicador do Direito, ainda quando crie Direito apenas uma norma individual ou execute uma sanção" (KELSEN, Hans. Teoria Pura do Direito, trad. loão Baptista Machado, 4a ed. Coimbra: Armênio Amado - Editor, 1979, p. 472).

7 Tradução de mutabilidade e de humildade é a passagem de CARNELUTT, Francesco. Diritto e Processo. Napoli: Morano, 1958, XXl, pela dual "chi vuol sapere perché, dopo tanti anni, continuo a studiare e a scrivere, sappia dunque che cosi faccio per correggere, fino a che posso, i mieri error"t.

8 MS 24.958-7/DF, Rel. Min. Marco Aurélio, j. 02.02.2005.

9 MS 24.997-8/DF, Rel. Min. Eros Grau, j. 02.02.2005.

${ }^{10}$ MS 25.015-1/DF, Rel. Min. Eros Grau, j. 02.02.2005.

"MS 25.036-4/DF, Rel. Min. Eros Grau, 1, 02.02.2005.

I2 MS 25.037-2/DF, Rel. Min. Eros Grau, 1. 02.02.2005.

13 MS 25.090-9/DF, Rel. Min. Eros Grau, j. 02.02.2005.

${ }^{14}$ MS 25.095-0/DF, Rel. Min. Eros Grau, j. 02.02.2005.

is MS 25.192-1/DF, Rel. Min. Eros Grau, 1. 07.04.2005. 
O Que assemelha tais decisões é o fato de Que, embora tenham tido um resultado unânime de concessão da ordem pleiteada, deixaram de reconhecer a decadência da potestade administrativa de invalidação ex officio de atos administrativos, sob o argumento de Que a jurisprudência daquela corte, segundo o Min. Eros Grau, tem "entendido que o ato de aposentadoria configura ato administrativo complexo, aperfeiçoando-se somente com o registro perante o Tribunal de Contas. Submetido, pois, a condição resolutiva, não se operam os efeitos da decadência antes da integração da vontade final da Administração" 16 .

Em outras palavras, entendeu-se, en relação aos atos sujeitos a registro ${ }^{17}$ pelos Tribunais de Contas, Que, embora tais atos administrativos tenham sido praticados há largo tempo, o prazo decadencial havido para a Administração Pública promover a sua invalidação não teria o seu termo inicial, senão após a decisão de registro do referido ato pela respectiva Corte de Contas, uma vez que somente após esse momento é que se poderia considerar perfectibilizado o ato administrativo.

Ora, em que pese o já referido papel do STF de "dizer" a Constituição Federal, bem assim da importância dos relatores dos arestos ora criticados - Min. Marco Aurélio e Min. Eros Grau -, Que tanto contribuem para a construção do Direito Público pátrio, Quer parecer Que tais decisões não se coadunam com a methor aplicação do princípio da proteção da confiança, o Qual se apresenta cada vez mais relevante à construção teórica do Direito Administrativo.

A demonstração de que a orientação jurisprudencial aqui criticada desgarra-se efetivamente do princípio acima referido (princípio da proteção da confiança), apresenta-se o objeto desse artigo, o Qual será dividido em duas partes.

Na primeira delas, tratar-se-á do enquadramento - ao que parece equivocado - dos atos sujeitos a registro pelos Tribunais de Contas como "atos administrativos complexos". Num segundo momento, as decisões acima referidas serão criticadas à luz do princípio da proteção da confiança.

:6 Tal passagem é encontrada em todos os Acórdãos acima referidos, relatados pelo Min. Eros Grau.

17 Em relação à categoria dos atos administrativos suịeitos a registro pelos Tribunais de Contas, tem-se a base normativo-constitucional no Artigo 71, Ill, da Carta Politica ("Art. 71. O controle externo, a cargo do Congresso Nacional, será exercido com o auxilio do Tribunal de Contas da União, ao qual compete: ... III apreciar, para fins de registro, a legalidade dos atos de admissäo de pessoal, a Qualquer título, na administrą̧äo direta e indireta, incluídas as fundaçôes instituídas e mantidas pelo Poder Público, excctuadas as nomeaçöes para cargo de provimento em comissão, bem como a das concessães de aposentadorias, reformas e pensóes, ressalvadas as melhorias posteriores que não atterem o fundamento legal do ato concessório;...") , Que embora se referia ao Tribunal de Contas da Uniäo, projetarse aos Tribunais de Contas dos Estados, do Distrito Federal e dos Municípios, Quando houver, por força do Arligo 75, também da CF/88. 


\section{ATOS SUJEITOS A REGISTRO PELOS TRIBUNAIS DE CONTAS E ATOS ADMINISTRATIVOS COMPLEXOS}

Dispõe o Artigo 71, da Constituição Federal18 ${ }^{18}$ Que compete aos Tribunais de Contas apreciar, para fins de registro, a legalidade dos atos de admissão de pessoal, ressalvados para os cargos em comissão, bem como a das concessões de aposentadorias, reformas e pensôes. Em outras palavras, uma vez investido um agente público em um cargo, emprego ou função pública, tais atos de provimento serão apreciados pelos respectivos Tribunais de Contas para fins de registro. Do mesmo modo, uma vez perpetrada a aposentadoria, a reforma ou o pensionamento de algum servidor, militar ou dependente de servidor público, esses atos de concessão de benefício previdenciário serão apreciados pelos Tribunais de Contas respectivos para fins de registro.

Tal "apreciação, para fins de registro", cumpre salientar, consiste na veriflcação, sem caráter jurisdicional, da legalidade ou, num sentido mais amplo, da validade dos atos administrativos benéficos àQueles Que são investidos em funções públicas, inativados ou pensionados pela Administração Pública ${ }^{19}$.

Em face da necessidade de Que a investidura e a inativação da maior parte dos agentes públicos sejam submetidas à apreciação e, por tim, ao registro pelos Tribunais de Contas, vários são os julgados exarados tanto pelo Supremo Tribunal Federal ${ }^{20}$ euanto pelo Superior Tribunal de Justiça ${ }^{21}$ no sentido de Que tais atos seriam "atos administrativos complexos" 2223 .

18 Uma interessante análise do desiderato e da organizaçâo dos Tribunais de Contas é encontrada em BRITTO. Carlos Ayres. O regime constitucional dos Tribunais de Contas, in Administraçăo Pública - Dirieto Administrativo, financeiro e gestão pública: prática, inovaçōes e polêmicas, org. Carlos Maurício Figueiredo e Marcos Nóbrega. São Paulo: RT, 2002, p. 97-109.

19 Nesse sentido, MEDAUAR, Odete. Controle da Administração Pública. São Paulo: RT, 1993, p. 135.

27) Além dos julgados acima referidos (vide notas 8-15), Que se fazem objeto dos comentáríos críticos aQui vertidos, podem ser citados os seguintes precedentes: MS 8.886, Rel. Min. Candido Motta, 1. 06.12.1963; MS 19.861, Rel. Min. Thompson Flores, 1. 31.03.1971; MS 19.873, Re]. Min. Amaral Santos, j. 09.06.1971; RE 195.861, Rel. Min. Marco Aurélio, j. 26.08.1997; MS 24.754, Rel. Min. Marco Aurélio, †. 07.10 .2004 .

2] REsp 1.560, Rel. Min. Carlos Velloso, 1. 05.02.1990; RMS 693, Rel, Min. Luiz Vicente Cernicchiaro, 1. 28.11.1990; RMS 6.777, Rel. Min. Gilson Dipp. 1 11.09.2001; EDd nos Edd no RMS 10.983, Rel. Min. José Arnaldo da Fonseca, 1. 1 1.12.2001.

27 Embora hậa algumas discordâncias, algumas inclusive inseridas no presente ensało, não se pode deixar de considerar interessante a abordagem sobre o pólo passivo do Mandado de Segurança quando da negativa de registro de atos de concessão de aposentadoria foi feita por HOMERCHER, Maria Cristina D'Arienzo. Da Autoridade Coatora no Mandado de Segurança em decisão denegatória de registro de ato de concessão de aposentadoria pelo Tribunal de Contas do Estado do Rio Grande do Sul. Porto Alegre, UFRGS, 2003 (Monografia realizada como pré-requisito para obtençăo do título de Especialista em Processo Civil - Processo e Constituiçăo).

${ }^{23}$ A orientação jurisprudencial dos Tribunais Supetiores, ademais, influencia decisões exaradas em Tribunais Inferiores, como se pode depreender dos El 70.010.318.798, $2^{\circ}$ Grupo de Câmaras Cíveis do TIRS, Rel. Desa. Matilde Chabar Maía, j. 11.02.2005 e AC 20020110501444, Rel. Des. Mario Belmiro, j. 22.11.2004, do TIDFT. Em sentido contrário, ou seja, no sentido das conclusöes desse trabalho, vide AC 2002110711652, Rel. Des. Silvânio Barbosa dos Santos, j. 16.08.2004, do TIDFT. 
Tal conclusăo, Qual seja, a de Que os atos sujeitos a registro seriam " atos administrativos complexos", rogando-se vênia à tradição e, pois, a Quem para ela contribuiu, não parece ser a mais correta. Além disso, mesmo que se entendesse correta tal premissa - atos sujeitos a registro são atos administrativos complexos -, ainda assim não se poderia chegar à conclusão de que a decadência da potestade administrativa de invalidação de atos viciados somente teria o seu termo inicial Quando do pronunciamento pelo Tribunal de Contas.

Com efeito, a classificação dos atos administrativos não pode ser considerada tema singelo. Isso porque, de um lado, apresenta-se árdua a tarefa de se catalogar uma categoria tão vasta e abrangente e, de outro, não se pode olvidar Que os critérios taxiológicos por vezes carecem de cientificidade. Isso porQue tais critérios de classificação são demasiadamente voltados à noção de utilidade, em detrimento da noção de correção. Não se pode olvidar a celebrizada passagem pela Qual as classificaçóes não poderiam ser classificadas como certas ou erradas, mas úteis ou inúteis ${ }^{24}$. Em solo pátrio, já se afirmou que " toda classificação em ciência é feita sob o critério da utilidade: as classificações são formuladas para servirem a algum fim. Elas não existem por si, isto é, näo derivam da 'natureza da coisa" ${ }^{\text {"25. }}$. Além disso, toda a tarefa de classificar e de delinear conceitos jurídicos apresentamse naturalmente tormentosa. Aos problemas de técnica jurídica, aliam-se outros - talvez mais complexos de linguagem, de metalinguagem, de hermenêutica ${ }^{26}$.

Especialmente na classificação Quanto à formaçáo, ou Quanto à composição de vontades, a classificação dos atos administrativos apresenta-se ainda mais tormentosa. Com base nesse critério, costuma-se dividir os atos administrativos em três espécies: atos administrativos simples, atos administrativos complexos e atos administrativos compostos.

Importante referir Que uma das razões da já referida dificuldade de serem os atos administrativos classificados Quanto à formação se dá justamente por que a diferenciação entre atos complexos e atos compostos é muito sutil, sendo que parte da doutrina se vale de uma classificação dicotomizada (atos simples e atos complexos). Opta-se, no presente ensaio pela divisāo tricotomizada supramencionada, porQuanto a dita sutil diferença entre atos complexos e atos compostos é justamente o cerne de um dos fundamentos pelos Quais se poderia considerar equivocada a orientação jurisprudencial aqui criticada.

${ }^{24}$ CARRIÓ, Genaro. Notas sobre Derecho y Lenguaje. Buenos Aires: Abaledo-Perrot, 1965. p. $72-$ 73.

${ }^{25}$ SUNDFELD, Carlos Ari. Fundamentos de Direito Público. 4. ed. São Paulo: Malheiros, 2000. p. 144.

to Ensina OLIVElRA, Regis Fernandes. Delegação e avocação administrativas, 2a ed. São Paulo: RT, 2004, p. 21 Que "Os lermos e conceitos jurídicos não se assemellham aos matemáticos. Não retratam perfis indeformáveis. Por constituirem-se em fórmulas verbais, os conceitos săo amoldáveis à linguagem comum, e seu uso, com diversos focos de significação, torna dificil a exata compreensão do conceito. Por vezes, alguns juristas empregam-no em certo sentido; outros usam-no diversamente, separando-o do significado comum. A divergência terminológica confunde". 
A análise da doutrina brasileira sobre a classificação dos atos administrativos Quanto à formação há de se iniciar pela compreensão dos ensinamentos de Hely Lopes Meirelles. Para o renomado autor, ato simples seria "o Que resulta da manifestação de vontade de um único órgão, unipessoal ou colegiado"27. lá o ato administrativo complexo seria "o que se forma pela conjugação de vontade de mais de um órgão administrativo". Assevera Hely Lopes Meirelles, ainda em relação aos atos complexos, Que tal categoria possuiria como elemento essencial "o concurso de vontades de órgãos diferentes para a formação de um ato único", razão pela qual "só se aperfeiçoa com a integração da vontade final da Administração, e a partir deste momento é que se torna atacável por via administrativa ou judicial' ${ }^{28}$. Por fim. o ato administrativo composto seria aquele que "resulta da vontade única de um órgão, mas depende da verificação por parte de outro, para se tornar exeQüíver ${ }^{29}$. Conclui, então, o autor que "o ato composto distingue-se do ato complexo porQue este só se forma com a conjugação de vontade de órgãos diversos, ao passo que aquele é formado pela vontade única de um órgão, sendo apenas ratificado por outra autoridade" ${ }^{* 30}$.

Em termos gerais, a classificação proposta por Hely Lopes Meirelles e o conceito de ato administrativo complexo, bem como a diferença entre esses e os atos compostos ${ }^{31}$ são seguidos pela doutrina brasileira ${ }^{32}$, embora sempre com alguns temperamentos ${ }^{33}$.

${ }^{27}$ MErRELLES, Hely Lopes. Direito Administrativo Brasileiro, $30^{\mathrm{a}} \mathrm{ed}$, atual. Eurico de Andrade Azevedo, Délcio Balestero Aleixo e josé Emmanuel Burle Filho. Săo Pauło: Malheiros, 2005, p. 171.

${ }^{28}$ MEIRELLES, Hely Lopes. Direito Administrativo Brasileiro, 30 a ed., atual. Eurico de Andrade Azevedo, Délcio Balestero Aleixo e José Emmanueł Burle Filho. São Paulo: Malheiros, 2005, p. 172.

29 MEIRELLES, Hely Lopes. Direito Administrativo Brasileiro, 30 a ed., atual. Eurico de Andrade Azevedo, Délcio Balestero Aleixo e José Emmanuel Burle Filho. São Paulo: Malheiros, 2005, p. 172.

30 ME!RELLES, Hely Lopes. Direito Administrativo Brasileiro, $30^{\mathrm{a}}$ ed., atual. Eurico de Andrade Azevedo, Délcio Balestero Aleixo e josé Emmanuel Burle Filho. São Paulo: Malheiros, 2005, p. 172.

${ }^{3 !}$ Conveniente recordar que tal diferenciação não é seguida por todos os autores que debruçaram suas atençōes sobre o tema.

32 BANDEIRA DE MELLO, Celso Antônio. Curso de Direito Administrativo, I $7^{a}$ ed. São Paulo: Malheiros, 2004, p. 390; BASTOS, Celso Ribeiro. Curso de Direito Administrativo. São Paulo: Saraiva, 1994, p. 109; CARVALHO FILHO, losé dos Santos. Manual de Direito Administrativo, 4aed. São Paulo: Lumen Juris, 1999, p. 87 88; Dl PIETRO, Maria Sylvia Zanella. Direito Administrativo, $17^{a}$ ed. São Paulo: Atlas, 2004, p. 215; GASPARINI, Diógenes. Direito Administrativo, $5^{a}$ ed. São Paulo: Saraiva, 2000, p. 74; IUSTEN FILHO, Marçal. Cułso de Direito Administrativo. Săo Paulo: Saraiva, 2005, p. 209; MUKAI, Toshio. Direito Administrativo Sistematizado. Săo Paulo: Saraiva, 1999, p. 213; OLVEIRA, Odília Ferreira da luz. Manual de Direito Administrativo. Rio de Janeiro: Renovar, 1997, p. 110: SEABRA FAGUNDES, Miguel. O controle dos atos administrativos pelo Poder Judiciário, $5^{a}$ ed. Rio de Janeiro: Forense, 1979, p. 38-40; TELLES, Antonio A. Queiroz. Introdução ao Direito Administrativo. São Paulo: RT, 1995, p. 59.

${ }^{33}$ Talvez os mais interessantes deles, pelo aprofundamento, sejam os propostos por ARAúfO, Edmir Netto. Curso de Direito Administrativo. São Paulo: Saraiva, 2005, p. 446-448; CAVAlCANTI, Themistocles Brandão. Tratado de Dircito Administrativo, Vol. I, Sa ed. Rio de laneiro: Freitas Bastos, 1955, 243246 e por CRETELLA júNIOR, losé. Curso de Direito Administrativo, $18^{\mathrm{a}}$ ed. Rio de Janciro, Forense, 2003, p. 168-172. Demais disso, deve-se apontar que alguns autores, embora não tenham divergências de fundo, atribuem outras denominações ao que considerou acima "ato administrativo complexo". como é o caso de MOREIRA NETO, Diogo de Figueiredo. Curso de Direito Administrativo, 11 a ed. Rio de laneiro: Forense, 1998, p. 107, ao preferir a terıninologia "ato administrativo conjunto", resguardando a expressão "ato complexo" para manifestações bi ou plurilaterais de vontades inediante comunhão de interesses. 
O Que chama a atenção, entretanto, é Que justamente esse conceito de ato complexo preconizado majoritariamente pela doutrina levaria à percepção de Que os atos administrativos sujeitos a registro pelos Tribunais de Contas não seriam enquadrados em tal categoria, embora o entendimento doutrinário em tela tenha sido empregado para a construção jurisprudencial aqui criticada, notadamente a decisão exarada por ocasião do julgamento ao Recurso Extraordinário ${ }^{\circ} 195.86 \mathrm{I}^{34}$.

Ora, se ato administrativo complexo é aquele para cuja formação ou existência, apresentam-se necessárias várias vontades conjugadas, os atos administrativos dependentes de registro pelos Tribunais de Contas não podem ser considerados atos administrativos complexos. Isso poreue todos os elementos de aperfeiçoamento de tais atos administrativos já são implementados quando da prática dos mesmos pela própria Administração Pública. A simples menção constitucional ao fato de Que a apreciação realizada pelos Tribunais de Contas tem como parâmetro a legalidade (ou validade) dos atos verificados induz, per se, a conclusão de que se tratam de atos já existentes.

Nesse sentido, não se pode olvidar a passagem já devidamente celebrizada de Pontes de Miranda, no sentido de que a legalidade (ou validade) é atributo de atos que existem $^{35}$. Ou seja, tendo o Tribunal de Contas o mister de apreciar a legalidade (ou validade) dos atos sujeitos ao seu ato de registro, não se pode considerar tal apreciação uma manifestação volitiva componente ou requisito de sua formação.

Demais disso, ainda a contribuir para o não-enquadramento dos atos sujettos a registro como atos complexos há de ser considerado um aspecto pertinente à sua produção de efeitos. Em efeito, tais atos sujeitos a registro (investidura, aposentadoria, pensionamento, etc) embora tenha a sua legalidade (ou validade) apreciada ulteriormente à sua efetivação pelos Tribunais de Contas, já produzem desde sua expedição e publicação todos os efeitos Que the são imanentes. Isso significa dizer que tais atos administrativos não dependem da apreciação e, ao final, do registro pelos Tribunais de Contas para produzirem a totalidade de seus efeitos, uma vez Que os mesmos já são produzidos desde a sua perpetração pela própria Administração Pública.

34 Vide nota 20.

35. "Para Que algo valha é preciso Quc exista. Não tem sentido falar-se de validade ou de invalidade a respeito do Que não existe. A questão da existência é questão prévia. Sòmente depois de se afirmar que existe é possível pensar-se em validade ou invalidade. Nem tudo que existe é suscetivel de a seu respeito discutir-se se vale, ou se não vale. Não se há de afinmar nem de negar Que o nascimento, a morte, ou a avulsão, ou o pagamento valha. Não tem sentido. Tăo-pouco, a respelto do que não existe; se não houve ato jurídico, nada há que possa ser válido ou inválido. Os conceitos de validade ou de invalidade só se referem a atos jurídicos, isto é, atos humanos que entraram (plano da existência) no mundo jurídico e se tornaram, assim, atos jurídicos" (PONTES DE MIRANDA, Francisco Cavalcanti. Tratado de Direito Privado, t. IV, $3^{\text {a }}$ ed. Rio de Janeiro: Borsoi, 1970, p. 7. Do mesmo modo, MELLo, Marcos Bernardes de. Teoria do Fato lurídico (plano da existência), $7^{\ddagger}$ ed. Săo Paulo: Saraiva, 1995. p. 79. 
Nesse sentido, tomando-se como exemplo do ato de concessão de aposentadoria de um servidor público inscrito no regime próprio (Art. 40, da CF/88), percebe-se Que uma vez concedida a aposentadoria pela Administração Pública, antes mesmo de o ato ser remetido para a apreciação pelo Tribunal de Contas respectivo, já ocorre a produção de todos os efeitos jurídicos decorrentes da inativação. Em efeito, somente com a concessão de aposentadoria pela Administração Pública, portanto, já se opera a vacância do cargo, podendo o mesmo ser prontamente provido por outro servidor ${ }^{36}$. Demais disso, não se pode olvidar que a legislação referente ao tema estabelece Que a aposentadoria compulsória é automática e tão-somente declarada por ato vigente a partir do dia imediato à implementação da idade-máxima de 70 $\operatorname{anos}^{37}$, encuanto Que a aposentadoria voluntária e por invalidez vigora a partir da publicação do respectivo ato ${ }^{38}$. Ou seja, uma vez implementada a idade-máxima, na aposentadoria compulsória, ou publicado o ato, nos casos de aposentadoria voluntária ou por invalidez permanente, o servidor já possuirá o status de inativo, passando a perceber proventos, ao invés de remuneração $0^{39}$. Importante salientar Que nada disso (vacância, inativação, proventos) exige o dito registro pelo Tribunal de Contas, correspondendo, ao contrário a efeitos já produzidos em face do simples ato de concessão pela própria Administração Pública.

O mesmo ocorre com o ato de investidura dos servidores público em cargos de provimento efetivo. Uma vez aprovados em concurso público, nomeados e empossados, os servidores gozarão de todos os efeitos decorrentes de sua condição funcional, independentemente de Qualquer pronunciamento, verificação ou registro pelo Tribunal de Contas. Assim, o conceito de servidor público ${ }^{40}$, a percepção da remuneraçãa ${ }^{41}$, a contagem do tempo de serviço ${ }^{42}$, o prazo para fins de estabilizaçãa ${ }^{43}$. o período aquisitivo de férias ${ }^{44}$, a condição de funcionário público para fins penais ${ }^{45}$, a condição de agente público para efeitos da Lei de Improbidade ${ }^{46}$, ou seja, todas as repercussōes decorrentes da condição de servidor púbilico, como visto, independem do registro do ato de investidura pelo Tribunal de Contas.

Ou seja, deve-se entender que os atos sujeitos a registro pelos Tribunais de Contas são formal e materialmente autônomos em relação ao ulterior pronunciamento pela respectiva Corte de Contas. A circunstância que thes peculiariza não condiz com o conceito de ato administrativo complexo, uma vez Que esse pressupöe manifestações de vontades conjugadas

\footnotetext{
${ }^{36}$ Em relaçāo aos servidores públicos federais, por exemplo, o Art. 33, VI, da Lei n ${ }^{\circ} 8.112 / 90$ preceitua que

"a vacáncia do cargo público decorterá de: ... aposentadoria....".

37 Vide Art. 187, da Lei $n^{\circ} 8.1 / 2 / 90$.

${ }^{38}$ Vide Art. 188 , da Lei $n^{\circ} 8.112 / 90$.

${ }^{39}$ Vide Art. 189, da Lei $n^{\circ} 8.112 / 90$.

${ }^{40}$ Vide Art. $2^{\circ}$, da Lei $n^{\circ} 8.112 / 90$.

41 Vide Art: 41 , da Lel $n^{\circ} 8.112 / 90$.

${ }^{42}$ Vide Art. 100, da Lei $n^{\circ} 8.112 / 90$,

${ }^{43}$ Vide Art. 21 , da Lei $n^{\circ} 8.112 / 90$ e, especialmente, o Art, 41, da CF/88.

${ }^{44}$ Vide Art. 77, da Lei ${ }^{\circ} 8.112 / 90$.

${ }^{45}$ Vide Art. 327, do CP.

${ }^{46}$ Vide Art. $2^{\circ}$, da Lei $n^{\circ} 8.429 / 92$.
} 
para a formação de um único ato administrativo. No caso em comento, tem-se duas manifestações de vontade Que não só são autônomas, como são formal e materialmente consistentes em atos (manifestações de vontade) autônomos.

Ainda a demonstrar dita autonomia havida entre o ato sujeito a registro e o registro propriamente dito, além do fato de que tais atos sujeitos a registro já produzem seus efeitos desde sua prática/publicação, deve-se recordar que a decisão de registro propriamente dita pressupõe, de forma autônoma, toda uma processualidade, na qual há de se observar, por exemplo, os princípios do contraditório e da ampla defesa. Nesse sentido, deve-se recordar um fato Que esclarece tal autonomia de vontade havida nos atos de registro, em relação ao ato objeto de tal verificação. Trata-se do fato de Que o próprio STF já se pronunciou, em diversas ocasiões, no sentido de que seria inválida a decisão de negativa de registro independente do ato sujeito a registro - em que não se observou os princípios do contraditório e da ampla defesa ${ }^{47}$. Ora, ineuestionável, pois, a autonomia de tal decisão.

Sendo assim, Quer parecer equivocado o enquadramento dos atos sujeitos a registro pelos Tribunais de Contas como atos administrativos complexos, porquanto esse pressupõe vontades conjugadas para a formação de um único ato, enquanto que no caso dos atos sujeitos a registro o Que se tem são duas decisões independentes e autônomas, Quais seja, o ato propriamente dito e o registro de tal ato.

Isso significa dizer Que, segundo a definição que se depreende da doutrina majoritária, os atos sujeítos a registro pelos Tribunais de Contas não seriam atos administrativos complexos, mas atos administrativos compostos. Para se alcançar tal conclusão, destaca-se o ensinamento de Maria Sylvia Zanella Di Pietro, para Quem “ato composto é o que resulta da manifestação de dois ou mais órgãos, em que a vontade de um é instrumental em relação a do outro, que edita o ato principal. Enquanto no ato complexo fundem-se vontades para praticar um ato só, no ato composto, praticam-se dois atos, um principal e outro acessório: este último pode ser pressuposio ou complementar daquele"48.

Ao contrário do que entende o STF, nos atos administrativos sujeitos a registro pelo Tribunal de Contas, a mecânica existente não consiste em uma manifestação de vontade sujeita a uma condição resolutiva, mas de duas manifestações de vontade - uma principal (o

${ }^{47}$ RMS 23.383, Rel. Min. Gilmar Mendes, I. 17.06.2003; MS 24.268, Rel. p/ Acórdão Min. Gilmar Mendes, 1. 05.02.2004; MS 22.357, Rel. Min. Gilmar Mendes, 1. 27.05.2004. Em relação à necessidade de contraditório e ampla defesa como condição para a extinção de atos administrativos benélicos aos seus destinatários o STF já havia se pronunciado, em especial, nas seguintes decisóes: RE 158.543, Rel. Min. Marco Aurélio, 1. 30.08.1994; RE 199.733, Rel. Min. Marco Aurélio, j. 15.12.1998. Todas essas decisões vão ao encontro da feição procedimenal da proteção às legítimas expectativas depositadas em atos estatais. Nesse sentido, vide: SCHONBERG, Soren 1. Legitimate cxpectations in Administrative Law. Oxford: Oxford Press, 2000, p. 31/63 e ÁVILA, Humberto. Benefícios fiscais inválidos e a legítima expectativa do contribuinte. Revista Diálogo lurídico, Salvador, CAI - Centro de Atualização Jurídica, $n^{\circ}$. 13, abril-maio, 2002. Disponivel na Internet: <http://wuw.direitopublico.com.br>. Acesso em: 22 de novembro de 2004, p. 2/5.

${ }^{48}$ DI PIETRO, Maria Sylvia Zanella. Direito Administrativo, $17^{a}$ ed. Săo Paulo: Atlas, 2004, p. 215 
ato sujeito a registro) e uma acessória e complementar (a decisão de registro de tal ato) -, ou seja, de dois atos administrativos, autônomos, seja Quanto à formação, seja Quanto aos efeitos, seja, por fim, Quanto aos princípios Que orientam suas respectivas perfectibilizações. Trata-se, pois, de ato composto e não de ato complexo.

Tal consideração - a de Que atos sujeitos a registro pelos Tribunais de Contas são atos administrativos compostos e não complexos - por representar um eQuívoco de premissa contido nas decisões aqui criticadas, já se prestaria a contraditá-las.

Ainda Que assim não fosse, ou seja, mesmo Que se entendessem tais atos sujeitos a registro como complexos, no sentido de Que a sua formação somente estaria aperfeiçoada Quando da decisão de registro pelo Tribunal de Contas, um outro aspecto - já referido poderia ser empregado para Que se concluísse pelo equivoco nuclear das decisões aqui criticadas, o de Que não se poderia falar em prazo decadencial senão após a decisão de registro pelo Tribunal de Contas. Trata-se do fato de que, como já mencionado acima, uma vez praticado/publicado um ato sujeito a registro ${ }^{49}$, todos os seus efeitos, notadamente os efeitos favoráveis aos seus destinatários, já são produzidos, independentemente de QualQuer pronunciamento oriundo da Corte de Contas incumbida de verificar a validade e registrar, pois, tal ato.

Em função disso, como será demonstrado no próximo item, mesmo que se considerassem os atos sujeitos a registro atos administrativos complexos - o que não é o caso - ainda assim, seria possível concluir Que as decisões aqui comentadas padeceriam do vício consistente na inobservância do princípio da proteção da confiança, consectário que é do princípio da segurança jurídica.

\section{A DECADÊNCIA DA POTESTADE ADMINISTRATIVA DE INVALIDAÇÃo DE ATOS E O PRINCÍPIO DA PROTEÇÃO DA CONFIANÇA}

Um dos consectários do Estado de Direito, previsto no Art. $1^{\circ}$, da $\mathrm{CF} / 88$ consiste justamente na exigência de Que toda a atividade estatal deva submissão à ordem jurídica constitucional ou infraconstitucional - por ele mesmo criada ${ }^{50}$.

29 Nomeaçăo para cargo efetivo, aposentadoria de servidor inscrito no regime próprio de previdência, concessão de pensão, por exemplo.

50 RE 158.215, Rel. Min. Marco Aurélio, 1. 30.04.1996; RE 154.159, Rel. Min. Marco Aurélio, 1. 10.06.1996; RE 158.655, Rel. Min. Marco Aurélio, j. 20.08.1996; RE 162.309, Rel. Min. Marco Aurélio, 1. 03.1 2.1996; RE 198.016, Rel. Min. Marco Aurélio, j. 01.04.1997; RE 170.463, Rel. Min. Marco Aurélio, 1. 16.12.1997; RE 223,230, Rel. Min. Marco Aurélio, j. 01 .06.1999; RE 215.624, Rel. Min. Marco Aurélio, 1. 16. [2.1999; RE 194.295, Rel. Min. Marco Aurélio, 1. 07.1 1.2000; RE 252.245, Rel. Min. Carlos Velloso, [. 14.11.2000; RE 242.064, Re!. Min. Marco Auréllo, 1. 14.11.2000; RE 247.262, Rel. Min, Marco Aurélio, 1. 13.02.2001. 
Em função disso, o princípio da legalidade, é colocado, por razões óbvias, em posição destacada nos estudos de Direito Administrativo ${ }^{51}$ desde o reconhecimento da autonomia científica de tal disciplina, o Que coincide, com o surgimento do próprio Estado de Direito em sua feiçẫo liberal ${ }^{52}$.

Depreende-se da legalidade, por seu turno, a potestade atribuída ao Estado, e aqui interessa à Administração Pública, de invalidar, extinguir, desconstituir os atos, condutas ou procedimentos que se apresentem, direta ou indiretamente, contrários ao Direito e à lei ${ }^{53}$. Tais prerrogativas extintivas de atos e condutas contrários à ordem jurídica representam, pois, manifestação da assim denominada "autotutela administrativa", desde há muito reconhecida no Direito Administrativo brasileiro ${ }^{54}$.

Ocorre Que a legalidade, embora extremamente relevante, não deve ser considerada como um "princípio absoluto" 55 . Trata-se, ao contrário, de um primado hermenêutico necessariamente instrumental, no sentido de oue a legalidade não traz consigo um fim em si mesmo. Isto é, não se pretende um estado de coisas decorrente da legalidade, por uma simples simpatia à legalidade.

51 Diz Celso Antônio Bandeira de Mello que "este la legalidade] é o princípio capital para a configuração do regime jurídico-administrativo" (BANDEIRA DE MELLO, Celso Antônio. Curso de Direito Administrativo, $17^{\star}$ ed. São Paulo: Malheiros, 2004, p. 90). Também nesse sentido, "a Direito Administrativo é determinado por toda uma série de princípios. O mais importante é, seguramente, o princípio da legalidade da administração pública" (MAURER, Hartmut. Elementos de Direito Administrativo Alemão. Trad. Luís Afonso Heck. Porto Alegre: Sérgio Antônio Fabris Editor, 200I, p. 45). Concorda-se com os ilustres autores - e este ao que parece é o contexto unicamente cabível - Quanto ao fato de que o princípio da legalidade é o mais tratado doutrinariamente e mais diretamente relacionado conn a atividade concreta ou normativa da Administração Pública. Uma hierareuização a priorie abstrata Que coloca a legalidade em posição de maior importância em relaçâo aos demais princípios, como se poderia depreender das passagens isoladamente consideradas não se apresenta, todavia, adequada.

52 SÉRVULO CORRElA, José Manuel. Legalidade e autonomia contratual nos contratos administrativos. Coimbra: Almedina, 1987, p. 19.

53 Vide, no plano federal, o disposto no Artigo $2^{\circ}, \S$ único, l, da Lei n ${ }^{\circ} 9.784 / 99$ ("A Administraçáo Pública obedecerá, dentre outros, aos principios da legalidade, finalidade, mothação, razoabilidade, proporcionalidade, morahdade, ampla defesa, contraditório, segurança jurídica, interesse público e eficiência. ... Parágrafo único. Nos processos administrativos seräo observados, entre outros, os critérios de: ... I - atuagăo conforme a lei e o Dircito"). É notável a influência do Artigo 20.3, da Constituição da Alemanha ("Die Gesetzgcbung ist an die verfassungsmäBige Drdnung, die vollziehende Gewalt und die Rechtsprechung sind an Gesetz und Recht gebunden").

54 Pode-se reconhecer como marcos da autotutela administrativa a edição, em 1963, da Súmula 346 ( $A$ Administraçăo Pública pode declarar a nulidade dos seus próprios atost e, posteriormente, em 1969, da Súmula 473 ( $A$ Administraçäo pode anular seus próprios atos, Quando envados de vícios que os tornam ilegais, porque deles nâo se originam direitos: ou revogá-los, por motivo de conveniência ou oportunidade, respeitados os direitos adquinidos, e ressalvada, em todos os casos, a apreciaçäo judiciah, ambas do STF.

55 Ora, năo é dado olvidar que "princípio absoluto", consoante os hodiennos estudos de hermenêtutica jurídica, consiste em uma contradiçĩo em termos, isso porque se algo é princípio jurídico não pode ser considerado absoluto e, sendo absoluto, nẫo se lhe pode reconhecer a feição de princípio. Demais dissso. para uma crítica à perspectiva totalizante e absoluta do princípio da legalidade, contrária, pois, ao seu próprio mister axiológico, vide OHLWELER, Leonel. Direito Administrativo em perspectiva. Porto Alegre: Livraria do Advogado, 2000. 
Como se afirmou, a legalidade administrativa consiste em um instrumento voltado à obtenção de segurança jurídica para, em conjunto com tal princípio constitucional, conformar a noção de Estado de Direito ${ }^{56}$. Daí porque se afirmar que "la seguridad jurídica no es solamente seguridad en legalidad, sino también, seguridad en el Derecho" ${ }^{57}$. Cumpre salientar Que, na maioria dos casos, a legalidade cumpre o seu desiderato instrumental de garantia da segurança jurídica e, assim, de conformaçäo do próprio Estado de Direito. Assim, não seria equivocado asseverar Que uma determinada conduta administrativa contrária à lei e ao Direito representaria, também, contrariedade à noção de Estado de Direito, razão pela Qual haveria de ser retirada no mundo jurídico, com efeitos retroativos, inclusive.

Ocorre Que, por vezes, em casos obviamente excepcionais, a legalidade induz a decorrências Que, ao invés de concretizar a segurança jurídica, culmina por contrariá-la, razão pela Qual se impõe a ponderação de tais valores, com vistas à consecução do Estado de Direito. Impôe-se, pois, como dito em outra época, Que a legalidade seja "temperada" com outros valores não menos relevantes à segurança jurídica ${ }^{58}$.

Desse fluxo de idéias, tem-se como um dos mais importantes instrumentos de ponderação da legalidade e da segurança jurídica a fixação de uma delimitação prazal para Que a Administração Pública exerça potestade Que lhe é outorgada de invalidar seus próprios atos administrativos. Eis a decadência administrativa Que, em termos gerais, e em relação ao plano federal, é prevista no Artigo 54, da Lei n ${ }^{\circ}$ 9.784/9959.

Trata-se de uma nítida manifestação do princípio da proteção da confiança, o Qual, dada a tradição eminentemente "legalista" do Direito Público pátrio, vem sofrendo indevidas resistências ${ }^{60}$. Com efeito, o princípio da proteção da confiança apresenta-se com uma

56 Pet 2.900 QO, Rel. Min. Gilmar Mendes, j. 27.05.2003.

57 LUENGO, lavier García. El principio de protección de la confianza en el Derecho Administrativo. Madrid: Civitas, 2002, p. 198.

SB O emprego da expressão "temperar a legalìdade com outros cânones da estabillidade das relaçôes jurídicas" deve-se a uma remissão a precedentes de lavra do eminente Min. Humberto Gomes de Barros, no Superior Tribunal de Justiça, dos quais se destacam o REsp 6.518, Rel. Min. Gomes de Barros, j. 19.08.1991 e o REsp 45.522, Rel. Min. Gomes de Barros, 1. 14.09.1994.

59 "O direito da Administração de anular os atos administrativos de Que decorram efeitos favoráveis para os destinatários decai em 5 (cinco) anos, contados da data em que foram praticados, salvo comprovada má-fé".

60 "... el principio de protección de la confianza legitima tiene un contenido realmente chocante para nuestra mentalidad juridico-administrativa, formada en ef respeto absoluto de la legalidad de la actuación administrativa. respeto que actúa como limite al juego de otros principios utilizados por nuestra jurisprudencia contenciosoadministrativa como el de la buena fe o el de los actos proprios, ya que permite mantener los efectos de determinadas situaciones ilegales, mantenimiento que se pustifica por la protección que merece el particular que confió legitimamente en la estabilidad de la situación juridica creada por la Administración. En tales supuestos, la seguridad juridica prima sobre el principio da legalidad de la actuación administrativa e impide a la Administración remover la situación favorable al Administrado por muy ilegal que sea" (MARIN RIAÑo apud BLANCO, Federico A. Castollo. La protección de confianza em el Derecho Administrativo. Madrid: Marcial Pons, 1998, p. 99). Almiro do Couto e Silva ensina, ainda, quc "A Administraçáo Pública brasileira, na quase totalidade dos casos, aplica o principio da legalidade, esquecendo-se completamente do 
dedução do princípio do Estado de Direito ${ }^{6 !}$ e da segurança jurídica, sendo dessa uma feição subjetiva ${ }^{62}$, tendo por precípua finalidade a obtenção de um estado de coisas que enseje estabilidade, previsibilidade e calculabilidade dos atos, procedimentos ou simples comportamentos das atividades estatais.

O referido mister, por seu turno, encontra concreção através de diversos instrumentos, dos Quais se destaca a preservação ou manutenção de atos administrativos ${ }^{63}$, mesmo que praticados de modo contrário à ordem jurídica, desde que a confiança neles depositada pelos seus destinatários seja legítima, em função da boa-fé́ ${ }^{64}$ e do decurso de um largo espaço de

principio da segurança juridica. A doutrina e a jurisprudência nacionais, com as ressalvas apontadas, têm sido muito tímidas na afirmação do princípio da segurança jurídica" (COUTO E SILVA, Almiro. Princípios da legalidade da Administração Pública e da segurança jurídica no Estado de Direito Contemporâneo. Revista de Direito Público, $n^{\circ}$ 84. São Paulo: Malheiros, out/dez 1987, p. 62).

${ }^{61}$ Nesse sentido, vide: CALMES, Sylvia. Du principe de protection de la confiance legitime en droits allemand, communautaire et français. Paris: Dalloz, 2001, p. 63 e HECK, Luís Afonso. O Tribunal Constitucional Federal e o desenvolvimento dos princípios constitucionais Contributo para uma compreensão da lurisdição Constitucional Federal Alemã. Porto Alegre: Safe, 1995, p. 186.

62 COUTO E SILVA, Almiro. O princípio da segurança jurídica (proteção à confiança) no Direito Público brasileiro e o direito da administração pública de anular os seus próprios atos administrativos: o prazo decadencial do art. 54 da lei do processo administrativo da Uniăo (Lei $n^{\circ} 9.784 / 99$ ). Revista de Direito Administrativo, $n^{\circ}$ 237. Rio de Janeiro: Renovar, jul/set 2004, esp. p. 272-276. Do mesmo modo CANOTILHO, losé Joaquim Gomes. Direito Constitucional e Teoria da Constiluição, $4^{a}$ ed. Coimbra: Almedina, 2000, p. 256, para Quem "o homem necessita de segurança para conduzir, planificar e conforma autônoma e responsavelmente a sua vida. Por isso, desde cedo se consideravain os princípios da segurança jurídica e da proteção à confiança como elementos constitutivos do Estado de direito. Estes dois principios - segurança jurífica e proteçăo da confiança-andam estreitamente associados, a ponto de alguns autores considerarem o principio da proteção da conflança como um subprincípio ou como uma dimensão especifica da segurança juridica. Em geral, considera-se que a segurança jurídica está conexionada com elementos objetivos da ordem juridica - garantia de estabilidade jurídica, segurança de orientação e realização do direito - enquanto a proteção da confiança se prende mais con as componentes subjectivas da segurança, designadamente a calculabilidade c previsibilidade dos indivíduos em relaçäo aos efeitos jurídicos dos actos".

${ }^{63}$ COUTO E SILVA, Almíro. O princípło da segurança jurídica (proteção à confiança) no Direito Público brasileiro e o direito da administração pública de anular os seus próprios atos adıninistrativos: o prazo decadencial do art. 54 da lei do processo administrativo da Uniäo (Lei $n^{\circ}$ 9.784/99). Revista de Direito Administrativo, $n^{\circ} 237$. Rio de laneiro: Renovar, jul/set 2004, esp. p. 274. Antes de tal trabatho, o ilustrado professor gaúcho já havia tratado do assunto em outros dois trabałhos: COUTO E SILVA, Almiro. Princípios da legalidade da Administração Pública e da segurança jurídica no Esiado de Direito Contemporâneo. Revista de Direito Público, $n^{\circ}$ 84. São Paulo: Malheiros, out/dez 1987 e COUTO E SILVA, Almiro. Prescrição Quïnqüenárla da pretensão amulatória da Administração Pública com relação a seus atos administrativos. Revista de Direito Administrativo, $n^{\circ} 204$. Rio de laneiro: Renovar, abr/jun 1996.

${ }^{6}$ PÉREZ, Jesús Gonzáles. El principio general de fa buena fe en el Derecho Administrativo, $3^{a}$ ed. Madri: Civitas, 1999, p. 55, para Quem " $Y$ así lo pone de manifiesto el resumen que se ofrece a continuación del régimen jurídico del principio de la confianza legítima. Los requisitos para que opere el principio y los efectos no difieren sustancialmente de los que constituyen el régimen juridico del principio de la buena fe". 
tempo. Tal delimitação prazal é prevista, no plano federal, no Art. 54, da Lei n ${ }^{0} 9.784 / 99^{65}$, Que concretiza a proteçâo da confiança e a segurança jurídica na medida em Que não permite a perpetuação da prerrogativa anulatória da Administração Pública, impondo a preservação de atos administrativos mesmo Quando inválidos, se ultrapassado, da prática do ato ou da fruição de seus efeitos patrimoniais, o prazo decadencial de cinco anos.

Cumpre salientar Que a decadência da potestade invalidatória Que se analisa reclama, basicamente, a conjugação de três requisitos legalmente previstas ${ }^{6}$. O primeiro critério diz respeito à natureza do ato administrativo, porQuanto somente se possa falar em decadência da potestade anulatória da Administração Pública Quando se tratar de atos Que produzem efeitos benéficos aos seus destinatários, ou seja, Quando de tratar de um " ato administrativo ampliativo" ${ }^{\prime \prime}$.

O segundo requisito exigido como critério de ponderação entre a proteção da confiança e a legalidade administrativa, também prevista pelo Artigo 54 , da Lei $n^{\circ} 9.784 / 99$, consiste na boa-fé do destinatário do ato, assim compreendida o fato de que esse não tenha contribuido para a invalidade Que eiva o ato ${ }^{68}$.

65 Importante ser dito que, em criticável providência, adotou-se o imperial instrumento previsto no Artigo 62 , da Constituição Federal, para, através da Medida Provisória $n^{\circ} 138$, de 20.11 .2003 , convertida na Lei $n^{\circ}$ 10.839/04, inserir-se o Artigo 103-A, à Lei $n^{\circ} 8.213 / 91$, o Qual previu que o "o direito da Previdência Social de anular os atos administrativos de que decorram efeitos favoráveis para os seus beneficiários decai em dez anos, contados da data em que foram praticados, salvo comprovada má-fé". Tal regra, Que obviamente não revogou o Artigo 54, da Lei n 9.784/99, trouxe norma especial em relaçâo à "Previdência Social", em Que se ampliou o prazo para 10 (dez) anos. Quanto ao novel dispositivo tem-se a dizer, inicialmente, Que o prazo decenário é exagerado e, portanto, näo alcança o desiderato de se dar concreçäo ao princípio da segurança. Ademais, "Seguridade Social' consiste em uma expressäo deveras ampla e carente de signiflicado, porquanto não denota nenhuma pessoa jurídica ou órgão público integrantes da Administração Pública Federal. Após tudo isso, a regra do Art. 103+A, da Lei n $8.213 / 91$ foi alterada por outra Medida Provisória. Qual seja a MP 242, a Qual, por seu turno, encontra-se suspensa por decisâo liminar exarada pelo Min. Marco Aurélio nas ADls 3467,3473 e 3505 .

* A inexistência de critérios obịtivivos e previamente determinados quanto à ponderação entre a legalidade e a proteção da conliança geraria, por mais paradoxal que pareça, um estado de insegurança jurídica. Ensina LUENGO. lavier García. El principio de protección de la confianza en el Derecho Administrativo. Madrid: Civitas, 2002, p. 88, Que "la falta de unos requisitos claros a la hora de determinar la aplicabilidad del principio de protección de la confianza genera, paradólicamente, inseguridad jurídica".

${ }^{67}$ Atos ampliativos "constituam direitos na esfera jurídica do destinatário, eliminem restriçöes ao exercício de direitos pré-existentes, eliminem ou restrinjam obrigaçôes, ou, ainda, que constituam na esfera furídica do particular situaçóes jurídicas aciivas diferentes dos direitos subjectivos, designadamente simples poderes ou faculdades" (SÉRVULO CORREIA, José Manuel. Legalidade e autonomia contratual nos Contratos Administrativos. Coimbra: Almedina, 1987, p. 290). No texto do Artigo 54, da Lei $\pi^{\circ} 9.784 / 99$. utilizou-se a expressão "atos de Que decorram efeitos favoráveis para os destinatários".

is Nesse sentido. importante referit o REsp. 603.135, Rel. Min. Teori Zavazcki, j. 08.06.2004, no Qual se deixou de aplicar a regra em comento em face da má-fé comprovada do destinatário do ato. 
Por fim, o último dos requisitos reclamados pelo Art. 54, da Lei n ${ }^{\circ} 9.784 / 99$, ou seịa, para a decadência administrativa corresponde ao prazo Qüinqüenário a contar da prática do ato viciado ou, no caso a efeitos patrimoniais contínuos, da percepção do primeiro pagamento. Trata-se de um critério flagrantemente objetivo, cuja aferição se faz, por isso mesmo, singela. O lapso temporal é, como não poderia deixar de ser, determinante para a implementação do prazo extintivo decadencial ${ }^{69}$.

Retomando-se a análise das decisões do STF que se fazem objeto do presente ensaio, tem-se justamente em relação a esse último reQuisito para a implementaçâo da decadência administrativa, o núcleo do Que parece ser a incorreção cometida pelo Pretório Excelso, na medida em que considerou no caso dos atos sujeito a registro pelos Tribunais de Contas - mal tidos como atos complexos - Que o termo inicial do prazo decadencial seria não a prática do ato administrativo sujeito a registro, mas do registro exarado pelo Tribunal de Contas.

Ora, a decadência administrativa corresponde a uma garantia Que terá o destinatário de um ato administrativo inválido para Que, mesmo reconhecida tal vício, não seja o ato administrativo anulado. No cerne de tal proteção, encontra-se a legitimidade da expectativa depositada pelo administrado. Considerando-se que tal expectativa se inicia não com o registro pelo Tribunal de Contas, mas com a prática do ato, é desse momento - e não daquele - que há de se iniciar a contagem do prazo de decadência administrativa.

Não se pode negar, pois, Que é da prática do ato --e não do registro - Que se inicia o "depósito" de confiança do ato administrativo sujeito a registro. Como se afirmou, tal ato apresenta-se formal e materialmente autônomo em relação ao seu ulterior registro. Desde a sua prática pela Administraçâo Pública, tal ato se entroniza no mundo jurídico, porquanto já implementa todos os pressupostos pertinentes ao plano da existência. Praticado o ato, ademais, seus efeitos já são todos produzidos, como se viu acima, independentemente do registro pelo Tribunal de Contas.

Demais disso, o ato administrativo sujeito a registro, uma vez praticado ou publicado, já se vê Qualificado pela presunção de legitimidade Que também auxilia na construção da confiança digna de proteção. Nesse sentido, não se poderia afirmar Que a presunção de legitimidade do ato somente teria início Quando da decisão de registro pelo Tribunal de Contas.

\footnotetext{
* Nesse sentido, pode-se dizer, tal como faz OTERO, Paulo. Legalidade e Administração Pública. $O$ sentido da vinculação administrativa à jurídicidade. Coimbra: Almedina, 2003, p. 1069, Que o "tempo desempenha em Direito Administrativo, tal como em qualquer outro sector do ordenamento, um papel de facto gerador do 'esquecimento' de situaçôes jurídicas contrárias ou conformes à legalidade jurídicopositiva, modificando e invertendo o seu sentido ou os seus efeitos".
} 
Ultima ratio, a confiança digna de proteção já se inicia com a prática do ato e nâo tãosomente com o seu registro, razão pela qual o prazo decadencial há de ter seu início Quando efetivamente se inicie a produção de seus efeitos ${ }^{70}$.

Um único exemplo concreto, extraído justamente das decisões aQui criticadas, será suficiente para a demonstração do Que se está sustentando. No caso do Mandado de Segurança $\mathrm{n}^{\circ} 25.015$, tinha-se a seguinte situação: o impetrante, militar reformado desde 1975 , acumulava tais proventos com os proventos decorrentes de aposentadoria em cargo civil de auxiliar de informações da ABIN, desde 1995, Quando se inativou na última das funções, até Que, em 2004, após negativa de registro pelo Tribunal de Contas, foi suspensa a percepção dos proventos decorrentes do cargo civil ${ }^{7}$. Percebe-se, pois, que do ato supostamente invalido (ato de aposentadoria no cargo civil) até a decisão de registro pelo Tribunal de Contas da União operou-se o transcurso de nove anos, nos Quais o impetrante se encontrava no pleno gozo dos efeitos benéficos decorrentes da aposentadoria.

Assim, se o Que se pretende com a decadência administrativa é a concretização do princípio da proteção da confiança e, com isso, a obtenção de um estado de segurança jurídica, impõe-se concluir que a decisão do STF não cumpre seu desiderato de guarda do Estado de Direito e, pois, da Constituição, ao deixar de reconhecer como termo inicial da decadência a prática do ato, para fazê-lo em relação tão-somente com a decisão de registro pelo Tribunal de Contas respectivo.

\section{CONCLUSÓES}

Não se nega Que se mostra extremamente desconfortável a posição de criticar uma significativa Quantidade de decisões exaradas pelo Supremo Tribunal Federal, seja pela autoridade que tal corte traz consigo, seja pelo reconhecimento técnico e pessoal de que cada um de seus membros é merecedor. Todavia, buscou-se no presente ensaio, o qual ambiciona incentivar ao debate, contrariar respeitosamente um posicionamento havido na Corte Constitucional, através da análise das premissas teóricas nele vertidas, com vistas a alcançar conclusões que podem ser assim resumidas:

70 Nesse sentido, pensando-se no princípio da proteção da confiança é que se referiu anteriormente que, para se demonstrar a incorreção das decisôes aqui criticadas, seria irrelevante quallilicar os atos sujeitos a registro como atos administrativos complexos ou compostos, porquanto de Qual Quer forma näo se poderia negar que o início da fruiçăa de seus efeltos se dá com a prática do ato sujeito a registro e não com a decisão de registro pelo Tribunal de Contas.

71 Importante recordar que, embora não se tenha reconhecido a alcgação de decadência, a ordem foi concedida sob o argumento de Que "o art. 93, $\$ 9^{\circ}$, da Constituição do Brasil de 1967, na redaçäo da EC 1/69, betn como a Constituição de 1988, antes da EC 20/98, não obstavam o retorno do milhtar reformado ao serviço público e a posterior aposentadoria no cargo civil, acumulando os respectivos proventos". 
- A destacada posição institucional atribuída ao Supremo Tribunal Federal, na interpretação, aplicação e guarda de Constituição Federal não se presta a imunizar de críticas as decisões exaradas naquela Corte, sendo imposto aos operadores do Direito Que se promova o exame do conteúdo decisório criticado, seja para com ele concordar, seja para dele discordar, sempre com vistas ao aprimoramento da Ciência Jurídica;

- Colocou-se sob lentes críticas a orientação jurisprudencial sedimentada por uma série de Mandados de Segurança julgados pelo STF, nos quais se deixou de reconhecer o início da contagem do prazo de decadência da potestade anulatória da Administração Pública em atos sujeitos à verificação pelos Tribunais de Contas, nos termos do Art. $7 \mathrm{I}$, III, da CF/88, senão após a decisão de registro;

- Ao contrário do Que entende o STF, como premissa teórica para a orientação criticada, os atos sujeitos a registro pelos Tribunais de Contas não são atos administrativos complexos, uma vez que esses consistem em atos para cuja formação é necessária a conjugação de vontades de órgãos ou entes diversos;

- Isso porque, de um lado, a verificaçăo realizada pelos Tribunais de Contas é pautada pela noção de legalidade (ou validade) do ato, o Que pressupõe a sua existência e, de outro, porque os atos sujeitos a registro e a decisão de registro propriamente dita săo formal e materialmente atos administrativos autônomos;

- A autonomia de tais atos, um principal (o ato sujeito a registro) e o outro acessório e complementar (a decisão de registro), é demonstrada pelo fato de que cada um deles surte efeitos jurídicos diversos, bem assim possuem pressupostos e formalidades independentes. Tratam-se, seguindo-se a doutrina majoritária, de atos administrativos compostos:

- A juridicidade, assim compreendida a necessidade de que a atividade estatal de administração pública seja adequada à ordem jurídica, é uma decorrência do Estado de Direito. razão pela qual a legalidade administrativa merece posição de destaque no Direito Administrativo;

- Todavia, a legalidade não se apresenta absoluta, na medida em Que possui o papel instrumental de garantir a segurança jurídica, outro princípio constitucional não menos relevante ao Estado de Direito. Assim, Quando as circunstâncias determinadas pelo princípio da legalidade afrontarem a segurança jurídica, a legalidade deverá ser ponderada com vistas à consecução do Estado de Direito;

- Dentre os mecanismos de ponderação entre a legalidade e a segurança jurídica, coloca-se em destacada posição o princípio da proteção da confiança, o Qual tem por precípua finalidade a obtençâo de um estado de coisas Que enseje estabilidade, previsibilidade e calculabilidade dos atos, procedimentos ou simples comportamentos das atividades estatais; 
- De tal princípio decorre, dentre outros institutos, a decadência da potestade de invalidação ex officio de atos administrativos Quando tais atos tenham sido praticados em benefício de seus destinatários, sem que esses tenham contribuído para a invalidade e já se tenha transcorrido, desde a prática do ato, um significativo lapso temporal;

- Considerando-se que tal prazo decadencial se fundamenta na confiança legitimamente depositada no ato pelo destinatário, Que os atos sujeitos a registro pelos Tribunais de Contas já produzem os seus efeitos desde a sua prática pela Administração Pública, bem como desde esse momento já se encontram portadores do atributo da presunção de legitimidade, a confiança depositada em tais atos apresenta-se legítima desde Quando a Administração Pública o pratica e não desde Quando venha o Tribunal de Contas a se pronunciar Quanto ao registro, razão pela qual é da prática do ato Que deve ser contado o prazo da decadência administrativa.

\section{REFERÊNCIAS BIBLIOGRÁFICAS}

ARAúfO, Edmir Netto. Curso de Direito Administrativo. São Paulo: Saraiva, 2005.

ÁVILA, Humberto. Beneficios fiscais inválidos e a legítima expectativa do contribuinte. Revista Diálogo Jurídico, Salvador, CA| - Centro de Atualização jurídica, $\mathrm{n}^{\circ}$. [3, abril-maio, 2002. Disponivel na Internet: <http://www.direitopublico.com.br > Acesso em: 22 de novembro de 2004.

BANDEIRA DE MELLO, Celso Antônio. Curso de Direito Administrativo, $17^{\text {a }}$ ed. São Paulo: Malheiros, 2004.

BASTOS, Celso Ribeiro. Curso de Direito Administrativo. São Paulo: Saraiva, 1994.

BLANCO, Federico A. Castollo. La protección de confianza em el Derecho Administrativo. Madrid: Marcial Pons, 1998.

BRITTO, Carlos Ayres. O regime constitucional dos Tribunais de Contas, in Administração Pública - Dirieto Administrativo, financeiro e gestão pública: prática, inovações e polêmicas, org. Carlos Maurício Figueiredo e Marcos Nóbrega. São Paulo: RT, 2002.

CALMES, Sylvia. Du principe de protection de la confiance legitime en droits allemand, communautaire et français. Paris: Da!loz, 2001.

CANOTILHO, José Joaquim Gomes. Direito Constitucional e Teoria da Constituição, $4^{\mathrm{a}}$ ed. Coimbra: Almedina, 2000.

CARNELUTTI, Francesco. Diritto e Processo. Napoli: Morano, 1958.

CARRIÓ, Genaro. Notas sobre Derecho y Lenguaje. Buenos Aires: Abaledo-Perrot, 1965.

CARVAlHO FILHO, José dos Santos. Manual de Direito Administrativo, 4aed. São Paulo: Lumen Juris, 1999. 
CAVALCANTI, Themistocies Brandão. Tratado de Direito Administrativo, Vol. 1, $5^{\text {a }}$ ed. Rio de laneiro: Freitas Bastos, 1955.

COUTO E SILVA, Almiro. Princípios da legalidade da Administração Pública e da segurança jurídica no Estado de Direito Contemporâneo. Revista de Direito Público, $n^{\circ} 84$. São Paulo: Malheiros, out/dez $[987$.

. Prescrição Quïnoüenária da pretensão anulatória da Administração Pública com relação a seus atos administrativos. Revista de Direito Administrativo, $n^{\circ} 204$. Rio de Janeiro: Renovar, abr/jun 1996.

. O princípio da segurança juŕ́dica (proteção à confiança) no Direito Público brasileiro e o direito da administraçẫo pública de anular os seus próprios atos administrativos: o prazo decadencial do art. 54 da lei do processo administrativo da União (Lei $n^{\circ}$ 9.784/99). Revista de Direito Administrativo, $n^{\circ} 237$. Rio de laneiro: Renovar, jul/set 2004. Forense, 2003.

CRETELLA JÚNIOR, José. Curso de Direito Administrativo, $18^{\text {a }}$ ed. Rio de laneiro,

DI PIETRO, Maria Sylvia Zanella. Direito Administrativo, $7^{7 a}$ ed. Sáo Paulo: Atlas, 2004.

GASPARINi, Diógenes. Direito Administrativo, 5a ed. São Paulo: Saraiva, 2000.

HART, Herbert L.A., The concept of Law, London: Oxford, 196I.

HECK, Luís Afonso. O Tribunal Constitucional Federal e o desenvolvimento dos princípios constitucionais - Contributo para uma compreensão da furisdição Constitucional Federal Alemã. Porto Alegre: Safe, 1995.

HOMERCHER, Maria Cristina D'Arienzo. Da Autoridade Coatora no Mandado de Segurança em decisão denegatória de registro de ato de concessão de aposentadoria pelo Tribunal de Contas do Estado do Rio Grande do Sul. Porto Alegre, UFRGS, 2003 (Monografia realizada como pré-requisito para obtenção do título de Especialista em Processo Civil - Processo e Constituiçáo).

JUSTEN FlLHO, Marçal. Curso de Direito Administrativo, São Paulo: Saraiva, 2005.

KELSEN, Hans. Teoria Pura do Direito, trad. João Baptista Machado, $4^{a}$ ed. Coimbra: Armênìo Amado-Editor, 1979.

LUENGO, Javier García. El principio de protección de la confianza en el Derecho Administrativo. Madrid: Civitas, 2002.

MAURER, Hartmut. Elementos de Direito Administrativo Alemão. Trad. Luís Afonso Heck. Porto Alegre: Sérgio Antônio Fabris Editor, 200 l.

MEDAuAR, Odete. Controle da Administração Pública. São Paulo: RT, 1993.

MEIRELLES, Hely Lopes. Direito Administrativo Brasileiro, $30^{\text {a }} \mathrm{ed}$., atual. Eurico de Andrade Azevedo, Déĺcio Balestero Aleixo e losé Emmanuel Burle Filho. São Paulo: Malheiros, 2005.

MELLO, Marcos Bernardes de. Teoria do Fato Jurídico (plano da existência), $7^{\mathrm{a}}$ ed. Säo Paulo: Saraiva, 1995. 
Saraiva, 1996.

MONTESQUIEU, O espírito das leis, trad. Pedro Vieira Mota. 4. ed. Säo Paulo:

MOREIRA NETO, Diogo de Figueiredo. Curso de Direito Administrativo, I la ed. Rio de Janeiro: Forense, 1998.

MUKAI, Toshio. Direito Administrativo Sistematizado. São Paulo: Saraiva, 1999.

OHLWEILER, Leonel. Direito Administrativo em perspectiva. Porto Alegre: Livraria do Advogado, 2000. Renovar, 1997.

OLIVEIRA, Odília Ferreira da Luz. Manual de Direito Administrativo. Rio de Janeiro:

OLIVEIRA, Regis Fernandes. Delegação e avocação administrativas, $2^{\text {a }}$ ed. São Paulo: RT, 2004.

OTERO, Paulo. Legalidade e Administração Pública. O sentido da vinculação administrativa à juridicidade. Coimbra: Almedina, 2003.

PÉREZ, lesús Gonzáles. El principio general de la buena fe en el Derecho Administrativo, $3^{a}$ ed. Madri: Civitas, 1999.

PONTES DE MIRANDA, Francisco Cavalcantì. Tratado de Direito Privado, t. IV, $3^{\text {a }}$ ed. Rio de laneiro: Borsoi, 1970.

SCHONBERG, Soren J. Legitimate expectations in Administrative Law. Oxford: Oxford Press, 2000.

SEABRA FAGUNDES, Miguel. O controle dos atos administrativos pelo Poder Judiciário, 5a ed. Rlo de Janeiro: Forense, 1979.

SÉRVULO CORREIA, José Manuel, Legalidade e autonomia contratual nos contratos administrativos. Coimbra: Almedina, 1987.

SUNDFELD, Carlos Ari. Fundamentos de Direito Público. 4. ed. São Paulo: Malheiros, 2000 .

TELLES, Antonio A. Queiroz. Introdução ao Direito Administrativo. São Paulo: RT, 1995. 